\title{
Effect of Drying Temperature of Small Scale Spray Dryer on Physical Properties of Coffee Powder
}

\author{
Joko Nugroho Wahyu Karyadi*, Dwi Ayuni, Tsania Ayu Rohani and Devi Yuni \\ Susanti
}

Departement of Agricultural and Bio-systems Engineering, Faculty of Agriculture Technology, Universitas Gadjah Mada, Jl. Flora Bulaksumur No.1, Kocoran, Caturtunggal, Depok, Sleman, Yogyakarta 5528, Indonesia

\begin{abstract}
Nowadays, coffee has become one of the most favorable commodities for beverages, flavoring as well as for cosmetic industries. In Indonesia, coffee becomes more popular, especially among youngsters. In this study, the spray drying process was evaluated, giving the potential of how simple spray dryer can help local farmers of Indonesia to produce their coffee powders. One small scale of spray dryer was constructed with the total dimensions of $2.85 \times 0.64$ for length $\mathrm{x}$ width, with a height of $2.32 \mathrm{~m}$. The spray dryer was equipped with a digital thermo regulator, the pneumatic nozzle system, and 4 finned heaters with the power of 2700 watt for each. The spray drying constructed was revealed to be able to produce coffee powders with fine quality. The inlet temperature of the drying chamber, as well as the initial Brix content of feed solution, were proven to affect the physical properties of powder produced such as moisture content, product yield, and solubility. The final moisture content of powders was ranged from $3-7 \% \mathrm{db}$, with the high product yield of the drying process, which could reach up to $70 \%$.
\end{abstract}

ARTICLE INFO

Article history:

Received: 7 May 2020

Accepted: 3 August 2020

Published: 21 October 2020

DOI: https://doi.org/10.47836/pjst.28.4.10

E-mail addresses:

jknugroho@ugm.ac.id (Joko Nugroho Wahyu Karyadi)

dwi.ayuni@mail.ugm.ac.id (Dwi Ayuni)

tsania.ayu.r@gmail.com (Tsania Ayu Rohani)

deviyunisusanti@ugm.ac.id (Devi Yuni Susanti)

*Corresponding author
Keywords: Coffee, product quality, product yield, spray-drying

\section{INTRODUCTION}

Coffee is one of the most promising commodities in the world with over US\$16 billion of the gross value of production, especially for green coffee. Concerning this 
in world total, coffee production in Indonesia has a total production of more than 700,000 tonnes in 2018, putting Indonesia as the fourth highest country for coffee production (FAO, 2018). From their total production, at approximately $62 \%$ coffee in Indonesia are exported while $38 \%$ of the rest are for domestic consumption (Nugroho, 2014). However, according to Hirschmann (2019), Indonesia's domestic coffee consumption has increased almost four times now since 1990. Local coffee products are also gaining in popularity, which can be seen from the instant coffee market.

A growing youthful population and the latest trends of coffee-drinking lifestyles are some contributing factors to the increases coffee demand. Besides, coffee shops with its emphasis on buying local, single-sourced beans that continue to expand in urban areas also gave the local coffee great potential to be recognized in a wider market. As the example, one study revealed that Robusta coffee farming in East Java Province, Indonesia was proven to be profitable and feasible, and was expected to be able to give a real contribution in the national economy, such as creating added value through postharvest, processing, and distribution activities (Winarno et al., 2018).

According to the research done by Wirunthanakrit and Vittayaporn (2018), development of Instant coffee can be done to have value added coffee products. Their research revealed that producing the coffee into instant coffee increased the chance of consumers purchase up to $88 \%$. Instant coffee, or soluble coffee, is a form of coffee available to consumers for quick hot coffee preparation. Instant coffee is made by taking extracts from coffee that has undergone a roasting process. This method was first introduced by Morgenthaler in Switzerland in 1938. The ground coffee has been extracted using certain pressures and extractors. The water steam used when taking the extract is $200^{\circ} \mathrm{C}$. The dry component contained in the extracted coffee is $15 \%$. Then the extraction results are dried using spraydryer and freeze-dryer to form powder (Belitz \& Grosch, 1987).

In the food industry, the most common process of powder formation is done by spray drying, since it has main advantages such as cost-effective, high yield, and a reduction of the product of exposure time to high temperature (Samantha et al., 2015). Spray drying is the process of converting a feed solution from a fluid into a dried particulate form by spraying the feed solution into a hot drying medium (Kuriakose \& Anandharamakrishnan, 2010), through an atomization process. As the feed emulsion contact with the hot air in the chamber, the moisture is removed and each droplet dried to form the powder. There are several types of atomizers available for spray drying. Among them are the rotary, nozzle, two-fluid, pressure and ultrasonic nozzle (Walzel, 2011). Atomization is a crucial part of the spray dryer because it influences the drying rate, particle diameter, particle distribution, and dispersibility of the powder for rehydration (Chegini \& Taheri, 2013). Drying airflow is another crucial factor in spray drying. The higher drying air flow rate will decrease the droplet drying time and lower the degree of water evaporation. This will lead to the 
insufficient drying process, and consequently producing higher moisture content in the final product (Shishir \& Chen, 2017).

Several studies have been done to evaluate the quality of coffee powder dried using mini lab spray dryer. The inlet temperature set as the drying condition were usually ranged from $150-220^{\circ} \mathrm{C}$ (Ishwarya \& Anandharamakrishnan, 2014; Villegas-Santiago et al., 2020; Wongsa et al., 2019). One study reported that spray-dried coffee exhibited higher antioxidant activity that that in freeze-dried coffee, due to the shorter drying time (Ghirisan $\&$ Miclaus, 2017). Other studies also revealed the potential of spray-drying coffee oil to later be used as an enhancement of aroma to the coffee beverages, flavoring, as well as cosmetics (Carvalho et al., 2014; Frascareli et al., 2012; Rodrigues \& Grosso, 2008).

However, in Indonesia the spray drying technology is still unaffordable for all coffee farmers, whereas only big scale factories are capable to produce instant coffee. This fact has encouraged the author to develop a simple and small scale of spray-drying that is relatively inexpensive to be made but of superior quality. Inlet temperatures of spray dryer as well as initial Brix content of feed solution are two important factors to determine the quality of the product. Therefore the objective of this research was to test the performance of spray drying constructed for coffee powder, based on the quality of the powder obtained including the moisture content, solubility, powder morphology, and color.

\section{MATERIALS AND METHODS}

\section{Sample Preparations}

Pure grinded coffee powder with specific renowned brand was purchased from a local market (Yogyakarta, Indonesia). Coffee powder was brewed in hot water $\left(90^{\circ} \mathrm{C}\right)$ at mixing ratio between coffee and boiling water of $1: 3(\mathrm{w} / \mathrm{w})$ before filtrating process. Diluted coffee extract obtained from the concentrated extract was used as feed solution, with three different variation of Brix content $\left(\mathrm{Bx}_{\mathrm{i}}\right): 10,20$, and $30 \%$.

\section{Spray Drying Process}

The spray dryer was designed in Laboratory of Food and Postharvest Engineering, and was manufactured in Laboratory of Energy and Agricultural Machinery of Universitas Gadjah Mada. The spray dryer had total dimensions of $2.85 \mathrm{x} 0.64$ for length $\mathrm{x}$ width, with height of $2.32 \mathrm{~m}$. The drying chamber had diameter of $0.60 \mathrm{~m}$, and the capacity spray dryer was 1.04 $\mathrm{kg} / \mathrm{h}$. Stainless steel 201 was chosen as construct material (Figure 1). The spray dryer was equipped with digital thermo regulator to set up the inlet temperature (Omron E5CSL-RTC, Omron Corporation, Kyoto, Japan), the blower to transfer hot air to the drying chamber (Sirocco DE150-6, Showa Denki Group, Osaka, Japan), the pneumatic nozzle system to form powder, 4 finned heaters with the power of 2700 watt for each, as well as cyclone to 
separate the hot air from the final product. Feed solution was transferred from feed stock to nozzle using a compressor of 2 Bar pressure. In this study, the spray dryer was operated with three variations of inlet temperature $\left(T_{i}\right): 180,200$, and $220^{\circ} \mathrm{C}$.

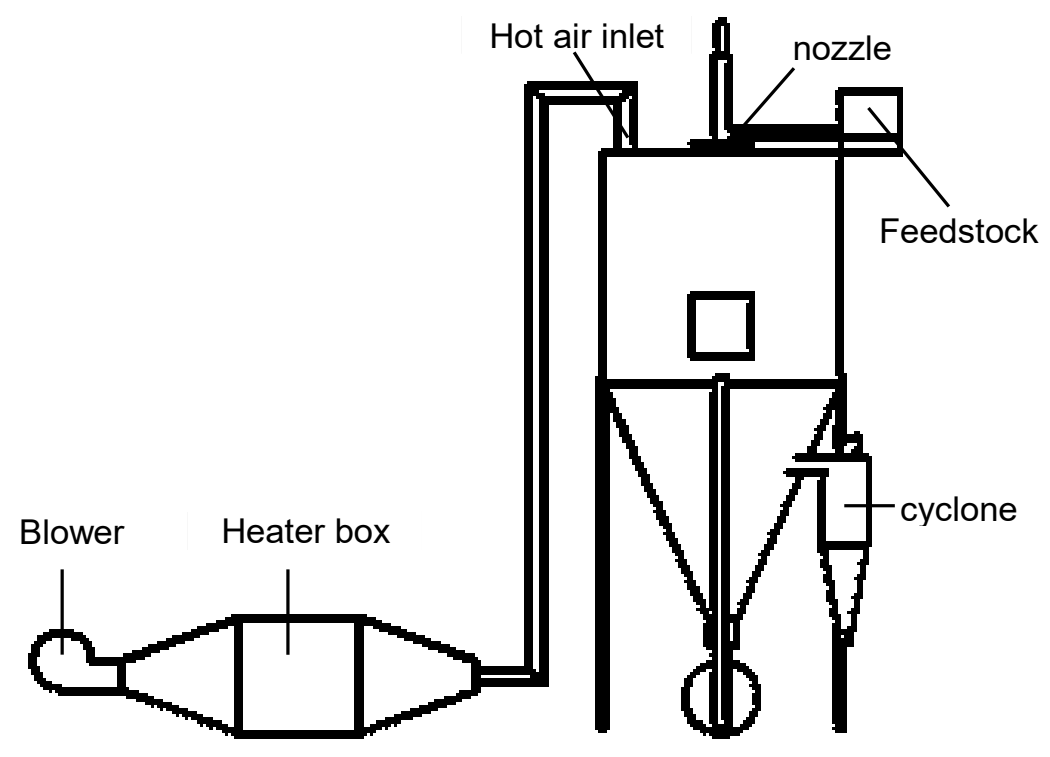

Figure 1. Spray dryer

\section{Moisture Content}

Particle moisture content was determined gravimetrically by drying in an oven (Memmert UM-400, Memmert GmbH + Co.KG, Schwabach, Germany) at $105^{\circ} \mathrm{C}$ for 24 hours (Park, 2008). The calculation of moisture content is presented by Equation 1.

$$
M=\frac{W-W_{1}}{W_{1}} \times 100 \%
$$

where $M$ is the moisture content ( $\% \mathrm{db}), W$ is the mass sample after spray drying process $(\mathrm{g})$, and $W 1$ is a dry matter of sample after 24 hours oven drying $(\mathrm{g})$.

\section{Product Yield}

Product yield is the ratio of mass of powder dry matter collected after drying to the weight of total solids in feed (Tontul \& Topuz, 2017), presented by Equation 2.

$$
\eta_{p o}=\frac{m_{p o}\left(1-M_{p o}\right)}{m_{\text {feed }}\left(1-M_{\text {feed }}\right)} \times 100 \%
$$


where $\eta_{p o}$ is the product yield (\%), $m_{p o}$ is the mass of powder, $M_{p o}$ is moisture content of powder, $m_{f e e d}$ is the mass of feed solution, and $M_{f e e d}$ is moisture content of feed solution.

\section{Color Analysis}

Color analysis was evaluated based on the components such as lightness $\left(L^{*}\right)$, redness/ greenness $\left(a^{*}\right)$ and yellowness/blueness $\left(b^{*}\right)$. The analysis was performed using Color Meter (Color Meter TES-135A, TES Electrical Electronic Corp., Taipei, Taiwan). Lightness, hue angle, and chroma values for each powder sample were reported. Hue angle $\left(^{\circ}\right)$ and chroma (-) were calculated using formula presented by Equation 3 and 4, respectively (Rahman et al., 2019; Da Silva \& Moreira, 2008).

$$
\begin{aligned}
& h_{a b}=\left(\frac{b^{*}}{a^{*}}\right) \\
& C^{*}=\sqrt{\left(a^{* 2}+b^{*^{2}}\right)}
\end{aligned}
$$

\section{Water Solubility Index}

Water solubility index (WSI) was determined using shake-flask method. 3 (three) g sample was suspended in $60 \mathrm{ml}$ distilled water, using magnetic stirrer (Advantec SRS710HA, Seisakusho Kaisha Ltd., Japan) set at $50^{\circ} \mathrm{C}$ for 10 minutes. The suspension then was centrifuged at $1000 \mathrm{x}$ for 10 minutes using table-top centrifuge (Kokusan H-27F, Kokusan Co.Ltd., Saitama, Japan). The insoluble residue was recovered and dried at $105^{\circ} \mathrm{C}$ for 24 hours. WSI (\%) was calculated using formula presented by Equation 5 (Kang et al., 2014).

$$
W S I=\frac{\text { insoluble residue weight }}{\text { original sample weight }} \times 100 \%
$$

\section{Wettability}

Wettability refers to the contact time of powder with water surface before it completely dissolved. The wettability was evaluated according to the method used by Edris et al. (2016). $0.5 \mathrm{~g}$ of the coffee powder was hydrated with $10 \mathrm{ml}$ distilled water. The time needed for full dissolution after mild stirring was recorded as wetting time.

\section{Powder Morphology}

Scanning electron microscopy (SEM; JSM 6510LA JEOL Ltd., Tokyo, Japan) was used to observe the enlarged image of the powder morphology of spray-dried powder. The sample was coated with Pt-Pd using an Auto Fine Coater before placed over the SEM. 


\section{Statistical Analysis}

Statistical analysis was performed using IBM SPSS Statistics 23 software (SPSS Inc., Chicago, IL). The properties of spray-dried powders were introduced to variance analysis (ANOVA, $95 \%$ significance level). Duncan test was used to test the homogeneity of variances among samples after the conditions for homogeneity of variances were achieved.

\section{RESULTS AND DISCUSSIONS}

\section{Physical Properties}

Table 1 shows the physical properties of coffee powder resulted from the spray drying process at different inlet temperatures and initial Brix content. The physical properties observed included moisture content, product yield, solubility, and wettability. Moisture content plays an important role in coffee handling since the low moisture content will prolong the shelf-life and preserve the quality of the products (Nakilcioğlu-Taş \& Ötleş, 2019). In general, the moisture content of coffee powders obtained ranged from $3-7$ $\% \mathrm{db}$, with the average value different among each sample. This result is similar to that found in previous studies (Bhadra et al., 2013; Ramalakshmi et al., 2007), that revealed the moisture content of coffee powder was maximally $7 \%$. In addition, according to the standard set by Indonesian National Quality Standard (SNI 2983:2014), the moisture content of instant coffee powder should not be more than $4-5 \%$. From Table 1, it can be seen that sample with higher initial Brix content resulted in powder with the lowest moisture content, ranging from $3-5 \% \mathrm{db}(\mathrm{p}<0.05)$. The higher the initial Brix content, the lower the moisture content remaining in the powder.

The effect of initial Brix content had significantly affected the product moisture content rather than the variation inlet temperature. It might be due to the fact that solids content determined the total amount of moisture available for evaporation (Ferrari et al., 2012). Therefore initial Brix content is a a strong contributing factor to the product moisture content. This result is different from the study done by Tan et al. (2011), who revealed that an increase in temperature would increase the drying rate; enhancing the efficiency of heat and mass transfer.

The product yield refers to how much the powder recovery can be achieved after the spray-drying process. From Table 1, it can be seen that the product yield was mainly affected by the initial Brix content in the feed solution. The higher the Brix content, the higher the product yield obtained $(\mathrm{p}<0.05)$. The highest yields achieved by $30 \%$ Brix were ranged from $70-75 \%$. Increasing the Brix content will reduce the moisture content available in powder, therefore improving the drying efficiency and powder recovery. This result is in agreement with Maury et al. (2005), who stated that less water was needed to be removed from each droplet with increasing solid's content. Meanwhile from the results obtained we could not see the distinctive tendencies of product yield caused by different 
Table 1

Physical properties of spray-dried powder of coffee

\begin{tabular}{|c|c|c|c|c|}
\hline \multirow{2}{*}{$\begin{array}{l}T_{i}\left({ }^{\circ} \mathrm{C}\right) / B x_{i} \\
(\%)\end{array}$} & \multicolumn{4}{|c|}{ Physical property } \\
\hline & $\begin{array}{l}\text { Moisture content } \\
(\% \mathrm{db})\end{array}$ & $\begin{array}{l}\text { Product yield } \\
(\%)\end{array}$ & Solubility (\%) & Wettability (s) \\
\hline $180 / 10$ & $6.46 \pm 0.22^{\mathrm{e}}$ & $31.98 \pm 2.23^{\mathrm{a}}$ & $51.56 \pm 7.44^{\mathrm{d}}$ & $\begin{array}{l}2975.10 \pm \\
150.30^{\mathrm{a}}\end{array}$ \\
\hline $200 / 10$ & $7.21 \pm 0.01^{\mathrm{f}}$ & $32.11 \pm 2.14^{\mathrm{a}}$ & $42.69 \pm 0.28^{\mathrm{abc}}$ & $2937.90 \pm 96.30^{\mathrm{a}}$ \\
\hline $220 / 10$ & $5.58 \pm 1.05^{\mathrm{d}}$ & $36.62 \pm 6.47^{\mathrm{ab}}$ & $47.38 \pm 5.95^{\text {bcd }}$ & $\begin{array}{l}3404.40 \pm \\
378.83^{\mathrm{b}}\end{array}$ \\
\hline $180 / 20$ & $5.48 \pm 0.19^{\text {cd }}$ & $41.40 \pm 5.63^{b}$ & $40.13 \pm 4.90^{\mathrm{ab}}$ & $\begin{array}{l}3685.50 \pm \\
361.50^{\mathrm{b}}\end{array}$ \\
\hline $200 / 20$ & $4.80 \pm 0.32^{\mathrm{bc}}$ & $41.13 \pm 0.14^{\mathrm{b}}$ & $36.48 \pm 3.02^{\mathrm{a}}$ & $3671.10 \pm 54.30^{\mathrm{b}}$ \\
\hline $220 / 20$ & $4.56 \pm 0.14^{b}$ & $51.54 \pm 0.92^{c}$ & $47.22 \pm 1.73^{\text {bcd }}$ & $\begin{array}{l}3768.30 \pm \\
143.70^{\mathrm{b}}\end{array}$ \\
\hline $180 / 30$ & $4.26 \pm 0.38^{b}$ & $74.06 \pm 2.58^{\mathrm{d}}$ & $45.96 \pm 0.78^{\mathrm{bcd}}$ & $\begin{array}{l}3462.00 \pm \\
138.00^{\mathrm{b}}\end{array}$ \\
\hline $200 / 30$ & $3.53 \pm 0.19^{\mathrm{a}}$ & $71.79 \pm 0.97^{d}$ & $49.28 \pm 1.09^{\mathrm{cd}}$ & $4779.60 \pm 25.80^{\circ}$ \\
\hline $220 / 30$ & $4.71 \pm 0.21^{\mathrm{b}}$ & $71.81 \pm 5.41^{\mathrm{d}}$ & $47.68 \pm 3.54^{\mathrm{bcd}}$ & $\begin{array}{l}4502.70 \pm \\
301.50^{c}\end{array}$ \\
\hline
\end{tabular}

Different superscript letters in the same column showed significant different at $(\mathrm{p}<0.05)$.

$T_{i}$ : inlet temperature; $B x_{i}$ : Brix content

inlet temperatures. Suzihaque et al. (2015) explained that increasing the temperature on spray drying could enhance the heat and mass transfer, but the extreme high temperature could cause the powder to melt and stick to the wall of the dryer, giving a negative effect to the product yield.

Solubility is known as the ability of the powder to fully dissolve in water to form a suspension. The wettability is the ability of the powder to overcome the surface tension between themselves and water, or a time required to give the powder wet completely. These parameters are very important as the indicator of coffee quality as drink powder. From Table 1, it can be seen that variances of inlet temperatures did not affect the solubility and wettability of powders obtained. Similar result was also reported by Al Mubarak et al. (2019), that the inlet spray drying temperature did not have a major effect on the water solubility index, bulk density, and hygroscopicity of Tamarillo powder. Meanwhile, the sample with $30 \%$ Brix were had the longest wetting time, ranged from $3500-4500 \mathrm{~s}$. This result is similar to that in coconut powder reported by A-Sun et al. (2016), who revealed that the higher solid content would reduce the porous structure of powder. This makes the water difficult to be absorbed, therefore prolonging the time needed for powder to be wet. 


\section{Color}

Figure 2 shows the results of lightness, hue angle, and chroma from the measuring of color using colorimeter. The lightness $\left(L^{*}\right)$ value of coffee powders obtained were ranged from $16-19$, which was associated with a very dark grey color. The hue angle value $(\mathrm{h})$ ranged from $0.3-0.5^{\circ}$. These values indicate that the red hue, similar to that reported by Villegas-Santiago et al. (2020). The chroma value ranged from $6-9$. These small value of chroma indicates the color is less pure, with low saturation. In conclusion, the color of coffee powders is referred as very dark red with low saturation. The inlet temperatures and Brix contents do not give any significant difference to the color component value. This could occurr because feed solution was entirely comprised coffee and water. Otherwise, the lightness could increase due to the dilution effect caused by the addition of wall material, such as maltodextrin. Another coffee spray drying process done by Wirunthanakrit and Vittayaporn (2018) reported that the color of instant coffee with $10 \%$ maltodextrin presented a lower L (brightness) value than $15 \%$.

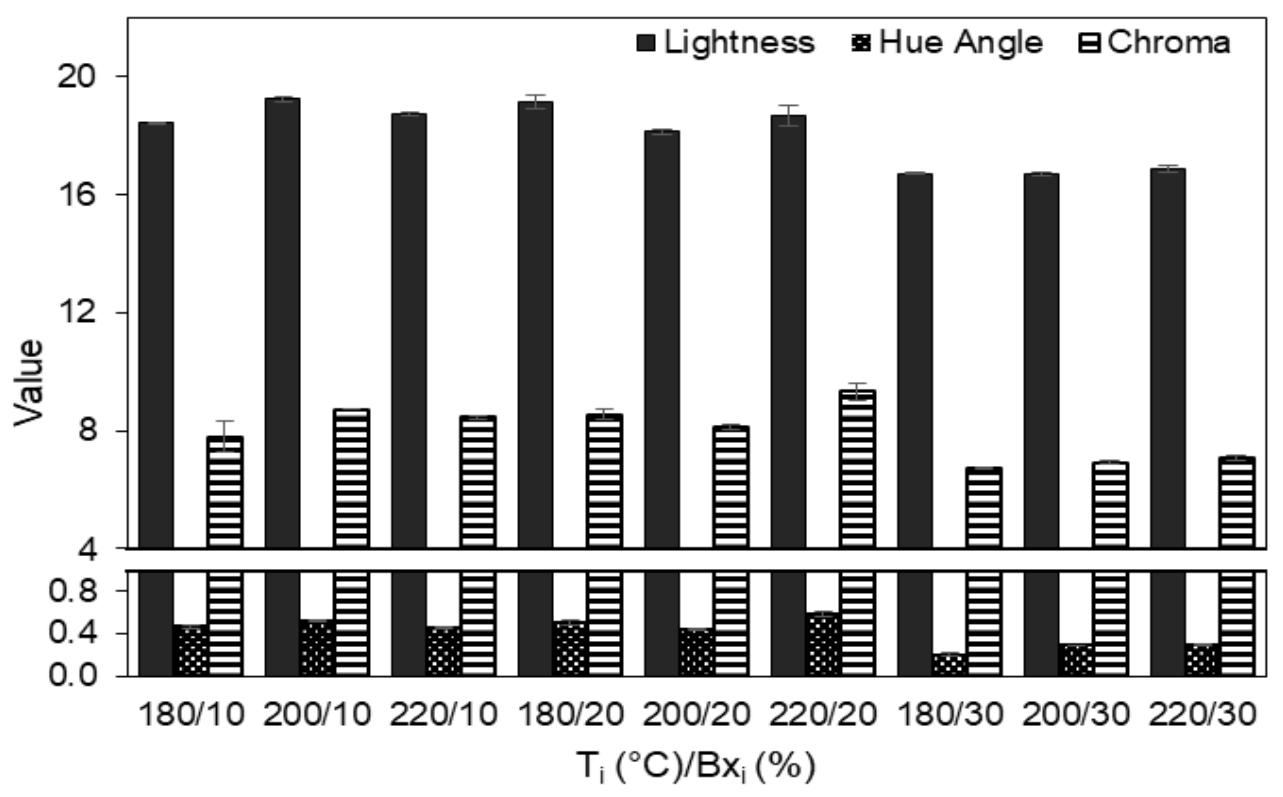

Figure 2. Color of spray-dried coffee at different inlet temperature $\left(\mathrm{T}_{\mathrm{i}}\right)$ and Brix content $\left(\mathrm{Bx}_{\mathrm{i}}\right)$

\section{Powder Morphology}

Figure 3 shows the morphology of the spray-dried powders of coffee studied by scanning electron micrographs. Analysis of the shape revealed that all the powders had had almost 
identical morphology, regardless of the operating conditions. The spray-dried powders were roughly spherical in shape, as described by other authors (Gallardo et al., 2013; Shamaei et al., 2017). The powders had a wide range of particle sizes, with the diameters of powders ranged from $11-31 \mu \mathrm{m}$. The surface of powders covered with big "pockmarks" and wrinkles. Previous studies confirmed this, stated that the presence of wrinkles may be happened due to the mechanical stress produced by uneven drying at different parts of liquid droplets during the first step of drying (Klinkesorn et al., 2006; Pourashouri et al., 2014; Teixeira et al., 2004). The pockmarks formed on the surface were varied in diameter, ranged from $3-12 \mu \mathrm{m}$. Besides, it can be presumed that the drying process has resulted in fine powders, proven by no agglomeration presented on the powder. The agglomeration could be formed due to the existence of surface oil, which caused the permanent link to form (Frascareli et al., 2012). The powders can be agglomerated and adhered one with another, formed a larger mass of powder compared to the rest samples.
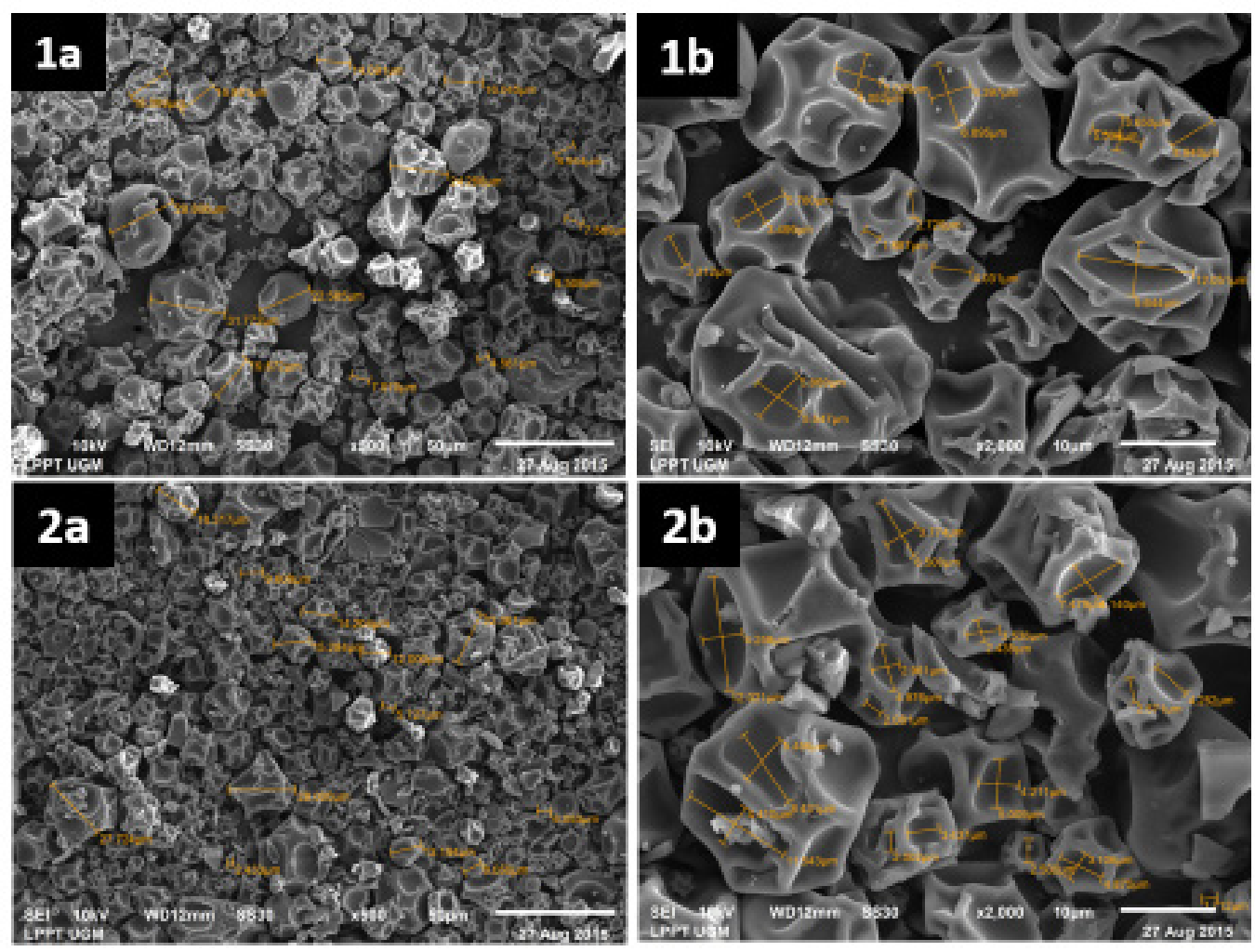

Figure 3. Micrographs of the outer morphology of coffee powders with initial Brix content of $20 \%$, inlet temperature of 180 (1), $200(2)$, and $220^{\circ} \mathrm{C}$ (3) and magnification of 500 (a) and 2,000 (b) 

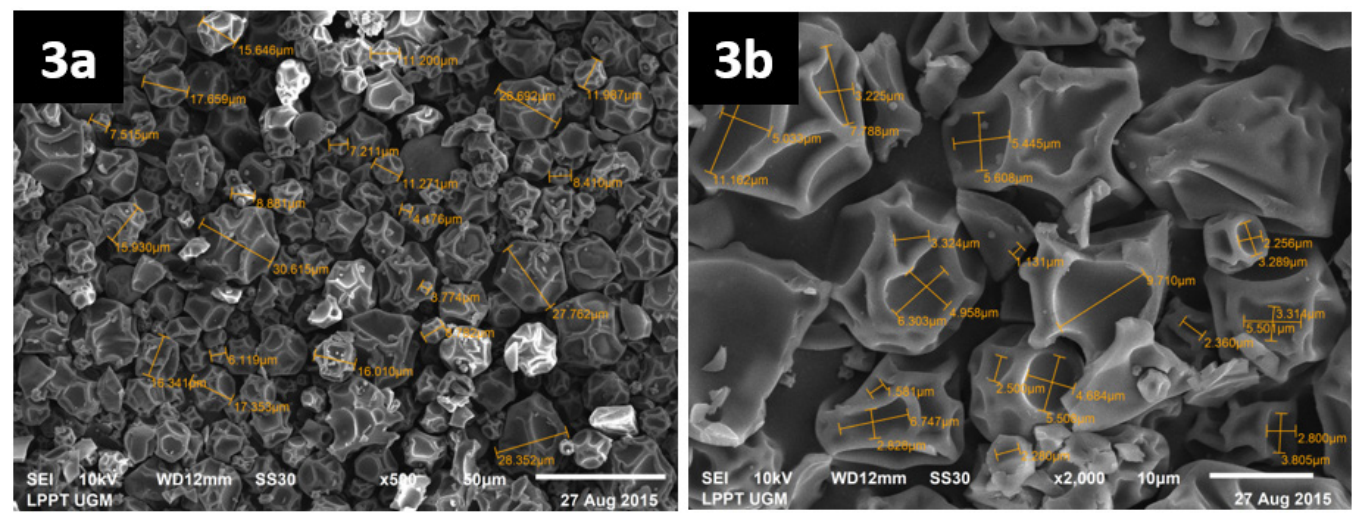

Figure 3. (Continued)

\section{CONCLUSION}

The performance evaluation of spray drying to form coffee powders was presented. The moisture content obtained ranged from $3-7 \%$, with their colors, be associated as dark red with low saturation. The SEM results indicate the powders to be finely formed with no agglomeration. The variation of Brix content gave more significant effect to the physical properties of powder compared to the variation of inlet temperature. Feed solution with $30 \%$ Brix resulted in lowest moisture content and highest product yield. This study has suggested that the simple spray drying can be constructed and work effectively to form coffee powders, to help farmers to gain the value-added for their coffee products.

\section{ACKNOWLEDGMENT}

We thank Prof. Bambang Purwantana and technicians of Laboratory of Energy and Agricultural Machinery of Universitas Gadjah Mada who have supported in construction process of spray dryer. This research was funded by the Faculty of Agricultural Technology of Universitas Gadjah Mada.

\section{REFERENCES}

A-Sun, K., Thumthanaruk, B., Lekhavat, S., \& Jumnongpon, R. (2016). Effect of spray drying conditions on physical characteristics of coconut sugar powder. International Food Research Journal, 23(3), 1315-1319.

Al Mubarak, A., Hamid, N., Kam, R., \& Chan, H. (2019). The effects of spray drying conditions on the physical and bioactive properties of New Zealand Tamarillo (Solanum betaceum) powder. Acta Scientific Nutritional Health, 3(12), 121-131.

Belitz, H. D., \& Grosch, W. (1987). Food chemistry. Berlin, Germany: Springer Verlag.

Bhadra, R., Rosentrater, K. A., \& Muthukumarappan, K. (2013). Measurement of sticky point temperature of coffee powder with a rheometer. International Journal of Food Properties, 16(5), 10711079. 
Carvalho, A. G. S., Silva, V. M., \& Hubinger, M. D. (2014). Microencapsulation by spray drying of emulsified green coffee oil with two-layered membranes. Food Research International, 61, 236-245.

Chegini, G., \& Taheri, M. (2013). Whey powder: Process technology and physical properties: A review. Middle East Journal of Scientific Research, 13(10), 1377-1387.

Da Silva, P. F., \& Moreira, R. G. (2008). Vacuum frying of high-quality fruit and vegetable-based snacks. LWT - Food Science and Technology, 41(10), 1758-1767.

Edris, A. E., Kalemba, D., Adamiec, J., \& Piaotkowski, M. (2016). Microencapsulation of Nigella sativa oleoresin by spray drying for food and nutraceutical applications. Food Chemistry, 204, 326-333.

FAO. (2018). Production of Coffee, green: Top 10 producers. Retrieved May 5, 2020, from www.fao.org/ faostat/en/\#data/QC

Ferrari, C. C., Germer, S. P. M., \& de Aguirre, J. M. (2012). Effects of spray-drying conditions on the physicochemical properties of blackberry powder. Drying Technology, 30(2), 154-163.

Frascareli, E. C., Silva, V. M., Tonon, R. V., \& Hubinger, M. D. (2012). Effect of process conditions on the microencapsulation of coffee oil by spray drying. Food and Bioproducts Processing, 90(3), 413-424.

Gallardo, G., Guida, L., Martinez, V., López, M. C., Bernhardt, D., Blasco, R., ... \& Hermida, L. G. (2013). Microencapsulation of linseed oil by spray drying for functional food application. Food Research International, 52(2), 473-482.

Ghirisan, A., \& Miclaus, V. (2017). Comparative study of spray-drying and freeze-drying on the soluble coffee properties. Studia UBB Chemia, 4, 309-316.

Hirschmann, R. (2019). Total coffee consumption in Indonesia 1990 - 2018. Retrieved May 5, 2020, from https://www.statista.com/statistics/314982/indonesia-total-coffee-consumption/

Ishwarya, S. P., \& Anandharamakrishnan, C. (2014). Spray-freeze-drying approach for soluble coffee processing. Journal of Food Engineering, 149, 171-180.

Kang, O. L., Yong, P. F., Ma'aruf, A. G., Osman, H., \& Nazaruddin, R. (2014). Physicochemical and antioxidant studies on oven-dried, freeze-dried and spray-dried agaro-oligosaccharide powders. International Food Research Journal, 21(6), 2363-2367.

Klinkesorn, U., Sophanodora, P., Chinachoti, P., Decker, E. A., \& McClements, D. J. (2006). Characterization of spray-dried tuna oil emulsified in two-layered interfacial membranes prepared using electrostatic layerby-layer deposition. Food Research International, 39(4), 449-457.

Kuriakose, R., \& Anandharamakrishnan, C. (2010). Computational fluid dynamics (CFD) applications in spray drying of food products. Trends in Food Science and Technology, 21(8), 383-398.

Maury, M., Murphy, K., Kumar, S., Shi, L., \& Lee, G. (2005). Effects of process variables on the powder yield of spray-dried trehalose on a laboratory spray-dryer. European Journal of Pharmaceutics and Biopharmaceutics, 59(3), 565-573.

Nakilcioğlu-Taş, E., \& Ötleş, S. (2019). Physical characterization of Arabica ground coffee with different roasting degrees. Anais Da Academia Brasileira de Ciencias, 91(2), 1-15. 
Nugroho, A. (2014). The impact of food safety standard on Indonesia's coffee exports. Procedia Environmental Sciences, 20, 425-433.

Park, Y. (2008). Moisture and water activity. In L. M. L. Nollet \& F. Toldra (Eds.) Handbook of processed meats and poultry analysis (pp. 35-67). Boca Raton, Florida: CRC Press.

Pourashouri, P., Shabanpour, B., Razavi, S. H., Jafari, S. M., Shabani, A., \& Aubourg, S. P. (2014). Impact of wall materials on physicochemical properties of microencapsulated fish oil by spray drying. Food and Bioprocess Technology, 7(8), 2354-2365.

Rahman, N. F. A., Ismail, A., Shah, N. N. A. K., Varith, J., \& Shamsudin, R. (2019). Effect of drying temperature on Malaysia pomelo (Citrus grandis (L.) osbeck) pomace residue under vacuum condition. Pertanika Journal of Science and Technology, 27(S1), 57-66.

Ramalakshmi, K., Kubra, I. R., \& Rao, L. J. M. (2007). Physicochemical characteristics of green coffee: Comparison of graded and defective beans. Journal of Food Science, 72(5), S333-S337.

Rodrigues, R. A. F., \& Grosso, C. R. F. (2008). Cashew gum microencapsulation protects the aroma of coffee extracts. Journal of Microencapsulation, 25(1), 13-20.

Samantha, S. C., Bruna, A. S. M., Adriana, R. M., Fabio, B., Sandro, A. R., \& Aline, R. C. A. (2015). Drying by spray drying in the food industry: Micro-encapsulation, process parameters and main carriers used. African Journal of Food Science, 9(9), 462-470.

Shamaei, S., Seiiedlou, S. S., Aghbashlo, M., Tsotsas, E., \& Kharaghani, A. (2017). Microencapsulation of walnut oil by spray drying: Effects of wall material and drying conditions on physicochemical properties of microcapsules. Innovative Food Science and Emerging Technologies, 39, 101-112.

Shishir, M. R. I., \& Chen, W. (2017). Trends of spray drying: A critical review on drying of fruit and vegetable juices. Trends in Food Science and Technology, 65, 49-67.

Suzihaque, M. U. H., Hashib, S. A., \& Ibrahim, U. K. (2015). Effect of inlet temperature on pineapple powder and banana milk powder. Procedia - Social and Behavioral Sciences, 195, 2829-2838.

Tan, L. W., Ibrahim, M. N., Kamil, R., \& Taip, F. S. (2011). Empirical modeling for spray drying process of sticky and non-sticky products. Procedia Food Science, 1(May 2015), 690-697.

Teixeira, M. I., Andrade, L. R., Farina, M., \& Rocha-Leao, M. H. M. (2004). Characterization of short chain fatty acid microcapsules produced by spray drying. Materials Science and Engineering C, 24(5), 653-658.

Tontul, I., \& Topuz, A. (2017). Spray-drying of fruit and vegetable juices: Effect of drying conditions on the product yield and physical properties. Trends in Food Science and Technology, 63, 91-102.

Villegas-Santiago, J., Gómez-Navarro, F., Domínguez-Niño, A., García-Alvarado, M. A., Salgado-Cervantes, M. A., \& Luna-Solano, G. (2020). Effect of spray-drying conditions on moisture content and particle size of coffee extract in a prototype dryer. Revista Mexicana de Ingeniería Química, 19(2), 767-781.

Walzel, P. (2011). Influence of the spray method on product quality and morphology in spray drying. Chemical Engineering and Technology, 34(7), 1039-1048.

Winarno, S. T., Darsono, Harisudin, M., \& Sudiyarto. (2018). Competitiveness analysis of Robusta coffee in East Java, Indonesia. Academy of Strategic Management Journal, 17(6), 1-10. 
Wirunthanakrit, W., \& Vittayaporn, V. (2018). Development of instant coffee for value adding of coffee products from Ban Borsiliam, Ngao District, Lampang Province. Journal of Food Health and Bioenvironmental Science, 11(3), 32-40.

Wongsa, P., Khampa, N., Horadee, S., \& Chaiwarith, J. (2019). Quality and bioactive compounds of blends of Arabica and Robusta spray- dried coffee. Food Chemistry, 283(May 2018), 579-587. 
